\title{
PREVALENCE OF SEROLOGIC TESTS ANTI HCV ON CHRONIC KIDNEY DISEASE (CKD) PATIENTS IN THE HEMODIALYSIS CLINIC PMI OF SURAKARTA CITY
}

\author{
Christina Roosarjani ${ }^{1}$, Saraswati KD ${ }^{1}$, Wahyuono $\mathrm{T}^{2}$ and Suparyatmo $\mathrm{JB}^{3}$ \\ ${ }^{1}$ Akademi Teknologi Bank Darah Surakarta, Indonesia \\ ${ }^{2}$ UDD PMI Kota Surakarta, Indonesia \\ ${ }^{3}$ Laboratorium Patologi Klinik RSUD Dr Moewardi, Indonesia
}

\begin{abstract}
Patients Chronic Kidney Disease (CKD) undergoing hemodialysis therapy classified as a high risk group infected with the hepatitis $C$ virus Type of research is to study the design retrospeksif. This research was conducted at the Clinic Hemodialysis PMI Surakarta. The study population was all patients with Chronic Kidney Disease (CKD) with HCV serologic test results were undergoing hemodialysis at the Hemodialysis Clinic Surakarta PMI indicates a reactive result. The research sample is CKD patients undergoing hemodialysis infected with chronic hepatitis C virus in Hemodialysis Clinic PMI Surakarta. In the results showed a group of men more prevalence of HCV serologic tests (53\%) than among women (47\%), the age groups most positive for HCV serologic results are above 60 years as many as 6 people (35\%). It is essential for the screening of anti HCV in CKD patients on hemodialysis time before action in a Hemodialisism Services unit, and evaluated periodically depending on the policy of each hemodialysis care unit. Also to reduce the prevalence of nosocomial infections, health workers always carry out universal precautions.
\end{abstract}

Keywords: Prevalence, Serological tests, Chronic Kidney Disease Patients.

\section{INTRODUCTION}

Chronic Kidney Disease (CKD) is also known as chronic kidney disease is a progressive loss of renal function over a period of more than three months with or without an accompanying reduction in the glomerular filtration rate (GFR). The symptoms of worsening kidney function is not specific, and there is a feeling uncomfortable and lack of appetite. CKD is often diagnosed as a result of screening of people known to have a risk of kidney problems as those who suffer from high blood pressure or diabetes mellitus and those whose blood pressure relative to $\mathrm{CKD}^{7}$.

Chronic Kidney Disease (CKD) patients undergoing Hemodialysis therapy are classified as high-risk groups infected with the Hepatitis $\mathrm{C}^{3}$ virus. This is mainly due to patients susceptible to HCV infection because of the risk of HCV exposure associated with their own dialysis process procedures, decreased cellular immunity function and exposure to blood products for a long time, also blood transfusions ${ }^{6}$. CKD patients infected with HCV can become carriers and potentially spread the virus to the hemodialysis space environment. Infection control equipment has been established to reduce the risk of HCV infection. The test to detect antibodies to HCV was first licensed by the Food and Drug Administration (FDA) in 1990 and is now being used throughout the world. Although there are rules for controlling infection in CKD patients, nosocomial transmission still occurs. The risk of HCV infection due to dialysis and blood transfusion has dramatically decreased ${ }^{6,8,13}$.

Hepatitis $\mathrm{C}$ in CKD patients can reduce life expectations. ${ }^{3}$ Hepatitis $\mathrm{C}$ virus infection (HCV) are more progressive in patients with terminal $\mathrm{CKD}$. In addition, $\mathrm{HCV}$ infection independently increased mortality of patients $\mathrm{CKD}^{3,13}$ role. To determine the transmission of hepatitis $\mathrm{C}$ in a hemodialysis clinic, Hepatitis $\mathrm{C}$ seroconversion in an HD unit is important to know. The prevalence of hepatitis C infection in patients with CKD in different countries varied from $2 \%-6 \%$ in the countries of Western Europe and North America, more than $20 \%$ in Japan and more than $60 \%$ in Saudi Arabia ${ }^{3,11,13}$. This variation appears to not only show the prevalence of HCV local but also aspects of dialysis patients increases the risk of developing $\mathrm{HCV}^{11,13}$.

Research on Hepatitis C seroconversion in Hemodialysis Clinic Surakarta PMI has never been done. Hemodialysis Clinic PMI in Surakarta current CKD patients with positive anti HCV are not isolated (as recommended by the Association of Nephrology Indonesia / Pernefri, 2006). Hemodialysis units in some hospitals, patients with positive anti-HCV seroconversion CKD using a dialyzer reprocessed. Dialyzer reprocessing for CKD patients with positive hepatitis C serology done separately. Currently dialyzer reprocessing is done with the help of machines. CKD patients with positive anti-HCV Clinical Hemodialysis uses a dialyzer PMI Surakarta single use to reduce the risk of seroconversion, hepatitis and other viral diseases ${ }^{13}$.

The use of erythropoietin that increases so that blood transfusion has been reduced. It is expected to decrease the prevalence of Hepatitis C HCV transmission order in CKD patients can be reduced, a variety of risk factors associated with hepatitis C 
seroconversion need to know, among other things long dialysis, hemodialysis in several places HD, history of surgery / other invasive procedures. In 1989, the Red Cross blood transfusion unit of Japan began using the first generation for the screening of blood donors for antibodies $\mathrm{HCV}^{11,13}$.

Some Hemodialysis units have their own rules to reduce the risk of transmission of hepatitis and HIV, among others, by laboratory examination procedure for parameter HBsAg, Anti-HCV and anti-HIV patients laboratory results three parameters has been more than 3 months. Reexamination of the hepatitis aims to obtain preliminary data of patients with CKD who will start therapy in hemodialysis unit, and there will be repeated with the period of time to monitor the possibility of hepatitis $\mathrm{C}$ seroconversion to positive ${ }^{13}$.

Given the importance of data Hepatitis $\mathrm{C}$ seroconversion, it is necessary to do some research to see an overview of Anti HCV serologic tests in patients with Chronic Kidney Disease (CKD) undergoing hemodialysis therapy in Kiinik Hemodialis PMI Surakarta.

Inspection methods IMLTD there are several kinds There are several types of immunoassay: enzyme immunoassay (EIA), radioimmunoassay (RIA), enzyme-linked immunosorbent assay (ELISA). And chemiluminescent enzyme immunoassay currently the examination methods most commonly used for diagnostic or screening of blood transfusion-transmitted infections (IMLTD) in donor blood. Another method is CLIA (Chemiluminescence Immunoassay) ${ }^{4,5,6,9,10,12}$.

CLIA (chemiluminescence immunoassay) is a type of immunoassay. Immunoassay is a biochemical test that measures the concentration of a substance in a fluid, usually blood serum or urine to see the reaction of antibodies to antigens ${ }^{4,5.6,9,10,12}$.

The benefits of this research are expected to be the information for reducing the Anti-HCV seroconversion positive patients with CKD who undergo hemodialysis therapy.

\section{METHODOLOGY}

Type of research is to study the design retrospeksif. This research was conducted at the Clinic Hemodialysis PMI Surakarta. The study population was all patients with Chronic Kidney Disease (CKD) with HCV serologic test results were undergoing hemodialysis at the Hemodialysis Clinic Surakarta PMI indicates a reactive result. The research sample is CKD patients undergoing hemodialysis infected with chronic hepatitis C virus in Hemodialysis Clinic PMI Surakarta.

The inclusion criteria for the study were all patients with CKD on Hemodialysis Clinic PMI Surakarta, examination results Anti HCV negative at the time of the first time in the HD Hemodialysis Clinic PMI Surakarta., Willing to be a sample by filling out informed consent. Exclusion criteria were patients already have positive HCV serologic test results when first HD in Hemodialysis Clinic PMI Surakarta.

samples taken from the patient when they first CKD undergoing HD therapy and when monitoring every 6 months after the first sample taken at the Hemodialysis Clinic PMI Surakarta from January to December 2016. The samples were checked for antiHCV by the method of CLIA (Chemiluminescence Immuno Assay). After the anti-HCV test results is completed, a total of 17 specimens are grouped according to age and gender.

\subsection{Operational Definition}

1. Patients Chronic Kidney Disease (CKD) Hemodialysis Clinic Surakarta PMI are all patients remained with a diagnosis of CKD grade $\mathrm{V}$ on HD undergoing hemodialysis procedure in Hemodialysis Clinic PMI Surakarta.

2. Anti-HCV serologic test is a test imunoserologi to see the levels of the hepatitis $\mathrm{C}$ virus antibodies in the patient's body using the CLIA (Chemiluminescence Immuno Assay).

3. The titer of anti-HCV is considered positive (reactive) when the concentration of anti-HCV through examination of CLIA (Chemiluminescence Immuno Assay) result $>1.0 \mathrm{IU} / \mathrm{ML}^{2}$.

\subsection{Data analysis}

Descriptive analysis is used to describe the characteristics of respondents and presents the results of research Anti HCV serologic test results positive in all patients with CKD.

\section{RESULTS}

The results of the study are listed in Table 1. Clinical Characteristics of Patients on Hemodialysis PMI CKD Surakarta, respondents of this study were 17 consisted of $9(53 \%)$ males and $8(47 \%)$ of women .. Total respondents divided into five groups: group I (ages 17-30 years) for 2 persons, group II (age 31-40 years) for 2 people and group III (ages $41-50$ years) as many as five people, group IV ((age 51-60 years) and group V (age> 60 years) as 6 people. In this study the data were also collected marital status, place of residence, education, occupation, history of blood transfusion ..

Pada tabel 1 terlihat sebagian besar responden tinggal di dalam kota Surakarta yaitu 2 responden (11,76\%) dan 14 responden $(88,23 \%)$ tinggal di luar kota Surakarta. Tingkat pendidikan responden terbanyak adalah SMA yaitu 10 responden $(58,82 \%)$ diikuti Akademi 4 responden (23,52 \%), SMP 2 responden $(11,76 \%)$ dan Universitas 1 responden $(5,88 \%)$ dan sisanya. Sesuai dengan tingkat pekerjaan responden, sebagian besar pekerjaan responden adalah pegawai negeri/ swasta adalah 5 responden $(29,41 \%)$, wiraswasta sebanyak 2 responden (11,76\%), pedagang sebanyak 3 responden (17,64 \%) dan lain-lain sebanyak 7 responden $(41,17 \%)$. 
International Journal of Advances in Scientific Research and Engineering (ijasre), Vol 5 (7), July-2019

Table 1. Characteristics of Respondents

\begin{tabular}{lcc}
\hline \multicolumn{1}{c}{ Characteristics } & Total (person) & $\%$ \\
\hline Marital status & & \\
- Single & 17 & 100 \\
- Married & 0 & 0 \\
Total & 17 & 100 \\
\hline Residence & 2 & 11.76 \\
- In the city & 15 & 88.24 \\
- Out of town & 17 & 100 \\
Total & & \\
\hline Level of education & 2 & 11.76 \\
- SMP & 10 & 58.82 \\
- SMA & 4 & 23.52 \\
- Academy & 1 & 5.88 \\
- University & 17 & 100 \\
Total & & \\
\hline Type of work & 0 & 0 \\
- Student & 5 & 29.41 \\
- Peg. State / private & 0 & 0 \\
- ABRI / TNI & 2 & 11.76 \\
- Entrepreneur & 3 & 17.64 \\
- Traders & 7 & 41.17 \\
- Etc & 17 & 100 \\
Total & & \\
\hline A history of blood transfusion & 3 & 17.65 \\
- Never transfusion & 14 & 82.35 \\
- 1-3 kolf / month & 0 & 0 \\
- > kolf / month & 17 & 100 \\
Total & & \\
\hline
\end{tabular}

The data shown in a graph to illustrate the prevalence of $\mathrm{HCV}$ positive serologic tests in patients with CKD on Hemodialysis Clinic PMI Surakarta.

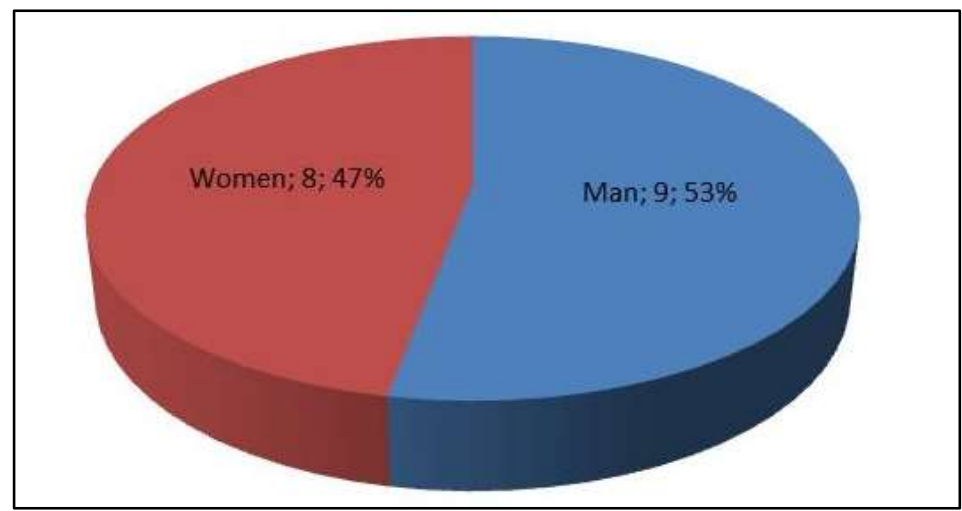

Figure 1. Data CKD patients with serologically positive Anti-HCV according sexes.

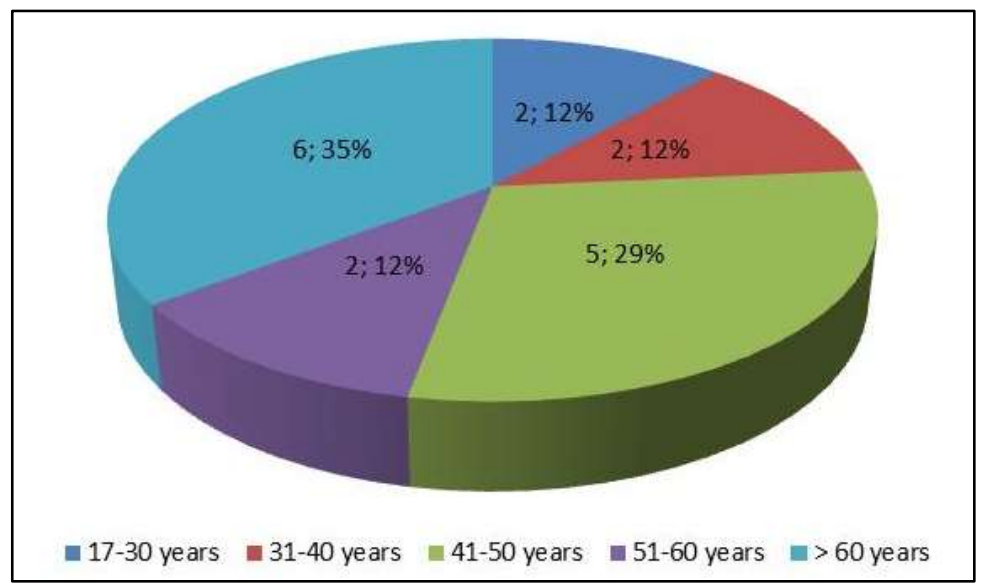


Figure 2. Data CKD patients with serologically positive Anti-HCV by age group

\section{DISCUSSION}

The results of the study of the majority of subjects were male to a ratio of males (53\%) and women (47\%). These results are as in previous studies by Dany (2013) which shows more suffering from Hepatitis C (Anti-HCV positive) than women ${ }^{1.2}$. New infection Hepatitis $\mathrm{C}$ is more common in HD units with the prevalence of hepatitis $\mathrm{C}$ is a higher and infection control failure. ${ }^{13}$

The possibility of hepatitis $\mathrm{C}$ infection that had occurred at the time before HD could not be removed. The patient can be in the window during the first examination. The source of transmission that can still occur pre HD is HD in other HD centers and blood transfusions performed before undergoing HD in the Surakarta City PMI Hemodialysis Clinic. The use of newer generation anti-HCV examinations can increase sensitivity and narrow the window period. The risk of getting anti-HCV results is negative in patients with a window period of $1: 103,000(1: 28,000-1: 280,000)^{2,3,13}$.

The possibility of transmission of hepatitis $\mathrm{C}$ is through a blood transfusion or dialysis equipment. Based on actual PERNEFRI every patient is undergoing anti-HCV HD checks every 6 months, but some patients don't have to do so with cost constraints. It is known that patients are a source of transmission of hepatitis $\mathrm{C}$.

Hepatitis C transmission can occur during blood transfusions or blood components (eg Packed Red Cells,) taken from the blood of an infected individual. It can be said that blood is very efficient for transmitting HCV infection. The frequency of seroconversion after blood infected with $\mathrm{HCV}$ is very high considering the HCV window period is very long, almost 2 months before the formation of antibodies in HCV. So far no studies have been reported in Indonesia in Hepatitis C cases related to blood transfusions. Transfusion blood from the PMI Surakarta Blood Donation Unit (UDD) has been screened with methods recommended by the Central Blood Donor Unit and according to the regulations of the Government through Minister of Health Regulation no. 91 of 2015 concerning Blood Transfusion Service Standards, namely CLIA (Chemiluminescence Immuno Assay) [4-6, 9-13.].

\section{CONCLUSION}

The results showed that the male group had more prevalence of HCV serological tests (53\%) than the female group (47\%), the most age group for positive HCV serologic results was over 60 years of age $(6 \%)$.

It is very important for Anti HCV screening in CKD patients before hemodialysis is performed in a Hemodialisism Service unit, and periodic evaluation is carried out depending on the policies in each unit of hemodialysis services. Also to reduce the prevalence of nosocomial infections, health workers always carry out universal precautions.

\section{REFERENCES}

1. Bakr I, et al, Higher clearance of hepatitis $C$ virus infection in females compared with males, Gut 2006;55:1183-1187. doi: 10.1136/gut.2005.078147.

2. Dany F, Handayani S, Seroprevalensi Hepatitis C pada Populasi Perkotaan dan Pedesan di Indonesia Tahun 2013 : Kajian Determinan Sosiodemografi, Lingkungan, Pejamu, dan Komorbiditas (Analisis Lanjut Riskesdas 2013), Media Litbangkes, Vol. 27 no. 4, DEsember 2017, 197-208.

3. El-Ottol AE, Elmanama AA, Ayesh BM, Prevalence and risk factors of Hepatitis $B$ and $C$ viruses among hemodialysis patient Gaza Strip,Palestine, Virology Journal 2010,7:210

4. Ilyas M, Ahmad I, Chemiluminescent microparticle immunoassay based detection and prevalence of HCV infection in district Peshawer Pakistan, Virol J, 2014; 11: 127.

5.. Majumder P, Shetty A K, Comparison between ELISA and chemiluminescence immunoassay for the detection of Hepatitis C virus antibody .Indian J Microbiol Res 2017;4(4):353-357.

6. Marwaha N, Sachdev S, Current testing strategies for hepatitis C virus infection in blood donors and the way forward, World J Gastroenterol 2014 March 21; 20(11): 2948-2954.

7. Matovinovic MS, Pathophysiologi and Classification of Kidney Diseases, EJIFCC. 2009 Apr; 20(1): 2-11

8. Ohsawa M et al, Standardized Prevalence Ratios for Chronic Hepatitis C Virus Infection Among Adult Japanese Hemodialysis Patients. J Epidemiol. 2010; 20(1): 30-39.

9. Permenkes RI no 91, 2015, Pemeriksaan Uji saring Darah dalam : Standar Pelayanan Transfusi Darah, hal :131-141.

10. Rini P et al,Uji Saring Antigen dan Antibodi Hepatitis C Virus pada Darah Donor, Buletin Penelitian Kesehatan, Vol. 43, No. 4, Desember 2015 : 213-218

11. Santosa D et al, Hepatitis C virus infection in Hemodialysis patients : Comparison of the Surabaya Dialysis Center and Juntendo University Hospital Dialysis Centre,Indonesian Journal of Tropical and Infectious Disease, Vol. 1. No. 3 September-December 2010: 105-109.

12. Soetjipto et al. Differential prevalence of Hepatits $C$ virus subtypes in healthy blood donors, patients on maintenance hemodyalisis, and patients with hepateluller carcinoma in Surabaya, Indonesia, J. Clin Microbiol 1996; 34 (12); $2875-80$.

13. Widhani A et al. Serokonversi Hepatitis C pada Pasien Hemodialisis di RS Ciptomangunkusumo,Jurnal Penyakit Dalam Indonesia. Vol. 2, No. 1: 15-21. 